\author{
AgnieszKa GromkowsKa-MelosiK \\ Uniwersytet im. Adama Mickiewicza \\ $w$ Poznaniu
}

\title{
KOPCIUSZEK: ZAGUBIONY SZKLANY PANTOFELEK I METAMORFOZY KOBIECOŚCI
}

\begin{abstract}
AвSTRACT. Gromkowska-Melosik Agnieszka, Kopciuszek: zagubiony szklany pantofelek i metamorfozy kobiecości [Cinderella: lost Glass Slipper and Metamorphosis of Femininity]. Studia Edukacyjne nr 46, 2017, Poznań 2017, pp. 61-69. Adam Mickiewicz University Press. ISSN 1233-6688. DOI: 10.14746/ se.2017.46.5
\end{abstract}

The article is devoted to the reconstruction of Cinderella myth in contemporary culture in the relation to the changing concepts of femininity. The Author takes into account several contexts of this issue. First, it can be understood in the terms of life as a lottery thanks to which in one moment a person is famous or rich (e.g. thanks to television success). Also, the author analyses the Cinderella in a light of sociological theory of competitive mobility. Besides sociotherapeutic Cinderella complex is analysed as well as feminist interpretation of Cinderella are reconstructed. The different versions of Cinderella fable are confronted with the various kinds of relations between women and men in contemporary. The Author shows also the examples of using the Cinderella myth in commercial advertising as well as politics and economy (Cinderella industry).

Key words: Cinderella, myth, femininity, interpretation

Mit Kopciuszka przenika kulturę naszych czasów. Jestem także przekonana, że będzie on przenikał naszą kulturę również w przyszłości. Na wstępie należy zauważyć, że odwołuje się on do metafory loterii, która zakłada możliwość nagłej zmiany w życiu, transformacji tożsamości, a przede wszystkim pozycji społecznej. Wygranie losu na loterii pozwala biedakowi stać się multimilionerem, podobnie jak zwycięstwo w jednym z niekończących się popularnych programów typu „Mam talent” stawia nikomu nieznaną dziewczynę z małego miasteczka w świetle reflektorów. Możemy tu odwołać się do eksponowanej w tekstach Zbyszka Melosika kategorii kultury natychmiastowości lub wręcz kultury instant ${ }^{1}$. Mam wrażenie, że żyjemy w świecie, w którym

1 Z. Melosik, Kultura popularna i tożsamość młodzieży. W niewoli władzy i wolności, Poznań 2014, s. 168-170. 
wszystko może stać się od razu, a protestancki ideał ciężkiej pracy odchodzi do przeszłości.

Kopciuszek, podobnie jak inne popularne bohaterki (i popularni bohaterowie), jest też bardzo podatny na komercjalizację, bowiem jego „ideologii” można doszukać się nawet w reklamach perfum, haseł „Podaruj sobie odrobinę luksusu", nie mówiąc już o reklamach samochodów, które obiecują w rezultacie ich zakupu przeistoczenie się w Księżniczkę (lub Księcia) Autostrady. Przywołam jeden z najbardziej trywialnych przykładów: 2014 rok. Kopciuszek w rozwianej fryzurze, nieco zniszczonej sukni, ze zbitym kolanem i z pięknym brylantowym bucikiem (podobno Prada) na jednej nodze, podjeżdża na wielkiej dyni, której towarzyszą trzy białe myszki, do McDrive'a. Na zegarze północ. Zdumiony pracownik podaje jej torbę z zamówieniem. Kolejna wersja klasycznej bajki? Nie, to kampania McDonalds zatytułowana „Come as you are" (Przyjdź w jakimkolwiek jesteś stanie)...

W innej reklamie, znanej brytyjskiej sieci domów handlowych Debenhams sprzedającej odzież, kosmetyki i upominki, motyw Kopciuszka winkorporowany zostaje $\mathrm{w}$ ideę natychmiastowej miłości, $\mathrm{w}$ dodatku umieszczonej zgodnie z ideą politycznej poprawności w klimacie wielokulturowości. Oto, w wagonie metra atrakcyjna kobieta napotyka wzrok niezwykle przystojnego czarnoskórego mężczyzny i bez wątpienia zakochują się w sobie od pierwszego wejrzenia. Na następnym przystanku kobieta opuszczając wagon metra, gubi srebrny pantofelek zakupiony w jednym z domów towarowych Debenhams. Cała fabuła reklamy skoncentrowana jest wokół poszukiwań wielkiej miłości, która niemalże natychmiast zaistniała między głównymi bohaterami. W ostatniej scenie, wieczorową porą na wyludnionym placu Londynu zupełnie przypadkowo czarnoskóry przystojny mężczyzna i kobieta odgrywająca rolę Kopciuszka spotykają się ponownie i natychmiast bez słowa oddają się namiętnym pocałunkom. Dodam, że postać Kopciuszka winkorporowana tu zostaje w bożonarodzeniową kampanię reklamową roku 2017.

Dość szokujące wykorzystanie motywu Kopciuszka spotykamy w indyjskiej reklamie Salonu Piękności dla Mężczyzn. Oto, w ciągu kilkudziesięciu sekund filmowej narracji mężczyzna, dzięki zabiegom kosmetycznym, zamienia się w pięknego księcia - mężczyznę o urodzie amanta. Co ciekawe, $\mathrm{w}$ ostatnim akcie traci swoje indyjskie rysy i przypomina klasyczną wersję męskiej urody w stylu amerykańskim. Mamy tu do czynienia z całkowitym wyjałowieniem postaci Kopciuszka ze źródłowych znaczeń.

Można również wskazać na reklamę Suzuki Maruti z wykorzystaniem motywu Kopciuszka, czy znakomicie skonstruowanej reklamy dżinsów Levisa, w której mężczyzna gubi spodnie, a piękna kobieta poszukuje ich właściciela wśród mężczyzn w restauracjach oraz innych publicznych miejscach, 
znajdując go wreszcie $\mathrm{w}$ warsztacie samochodowym. I w tym przypadku mamy do czynienia $\mathrm{z}$ odwróceniem tradycyjnego motywu Kopciuszka.

$\mathrm{Z}$ kolei, w jednej z azjatyckich reklam szamponu przekonuje się, że pozwoli on na natychmiastowe przeistoczenie się w postać pięknej księżniczki. Motyw Kopciuszka zostaje też wykorzystany w reklamie opon Ventus S1.

W niniejszym tekście spróbuję przedstawić wybrane konteksty ideologiczne i teoretyczne postaci Kopciuszka. Pierwszy z nich dotyczy wykorzystanych w tekstach Ralpha Turnera - ruchliwości konkurencyjnej i sponsorowanej ${ }^{2}$. Kopciuszek zdaje się uosabiać obydwie z nich. Z jednej bowiem strony skromna i wykonująca najcięższe prace domowe, bez nadziei na lepsze jutro, dziewczyna dzięki pomocy swojej Matki Chrzestnej (która obdarza ją stosownym ubraniem i pojazdem) spotyka na balu Księcia i przeskakuje w górę o kilka klas społecznych stając się Księżniczką. Zostaje wybranką i staje się natychmiast częścią elity (w ruchliwości sponsorowanej to członkowie elity dobierają arbitralnie członków do swojego kręgu na podstawie ich pewnych atrybutów ${ }^{3}-w$ tym przypadku jest to uroda). Tak więc w wypadku Kopciuszka główna bohaterka potrzebuje innych, znaczących osób, dzięki pomocy których przemienia się w Księżniczkę. W przypadku Kopciuszka mamy do czynienia również z ruchliwością konkurencyjną, bowiem konkurentek do przymierzenia bucika i stania się żoną Księcia jest wiele, ale to właśnie skromna dziewczyna wygrywa w tym współzawodnictwie.

Nie ulega wątpliwości, że motyw Kopciuszka jest dla milionów ludzi znacznie bardziej atrakcyjny niż idea self-made-man (który dzięki ciężkiej pracy, krok po kroku, wspina się przez dekady po drabinie społecznej).

Kopciuszek stanowi jedną z tych symbolicznych postaci kultury, która odwołuje się do masowej wyobraźni milionów dzieci na świecie, a w szczególności dziewczynek (w różnym wieku) - przecież Barbie jako Kopciuszek zdobyła wśród nich niezwykłą popularność. Metaforyczne oddziaływanie tego symbolu na różne sfery życia jest tak znaczące, że mamy do czynienia z szeregiem zjawisk, procesów i mechanizmów określanych imieniem głównej bohaterki (niekiedy używanym też w formie przymiotnika).

Można wyjść tu od funkcjonującego w psychoterapii „kompleksu Kopciuszka" (Cinderella Complex), definiowanego jako strach przed niezależnością i związanego z socjalizowaniem dziewcząt w rolę podległej i biernej kobiety, która nie potrafi sama poradzić sobie w życiu i musi opierać się na innych (najlepiej mężczyznach) ${ }^{4}$. Takie kobiety mają niskie poczucie własnej wartości i wchodzą w destruktywne czy toksyczne relacje z mężczyznami; z jednej

2 Por. Z. Melosik, Uniwersytet $i$ społeczeństwo. Dyskursy wolności, wiedzy i władzy, Poznań 2009, s. 119-122.

3 Tamże.

${ }^{4}$ C. Dowling, The Cinderella Complex: Women's Hidden Fear of Independence, New York 1981. 
strony pragną być od nich zależne, ale jednocześnie często stawiają im nierealistyczne oczekiwania ${ }^{5}$.

W odczytaniach feministycznych Kopciuszek jest krytykowany za kreowanie scenariusza kobiecej podległości, koncentracji na tym co zewnętrzne: urodzie i młodości, a także wyznaczeniu głównego celu życiowego kobiet: znalezienia odpowiedniego męża/partnera. Uważa się także, że promuje on postawę bierności i akceptowania roli ofiary ${ }^{6}$.

A jednak, to właśnie Kopciuszek „esencjalnie niejednoznaczny i dialogiczny", zbudowany wokół "dychotomii pragnienie/samopoświęcenie się, namiętność/rozum" ${ }^{7}$ staje się wdzięcznym obiektem feministycznych rewizji, przekształceń i parodii. Mit Kopciuszka, jak pisze Donald Haase, funkcjonuje w kulturze jako "dwuznaczna lub wieloznaczna ideologiczna bron" ${ }^{8}$. Jego zdaniem, mamy tu do czynienia z dwoma przekazami: „kodem dobrego wychowania troskliwie wplecionym w romantyczny mit podporządkowanej i udomowionej kobiecości w ramach patriarchii", ale także z protestancką ideą indywidualizmu włączającego poczucie jednostkowej godności i potrzeby samorealizacji ${ }^{9}$.

Warto także krótko przeanalizować feministyczną wersję Kopciuszka, autorstwa Emmy Donoghue z tomu Kissing the Witch. Old Tales in New Skins, zatytułowaną The Tale of the Shoe. Główna bohaterka jest narratorką powieści, która w sposób bardzo refleksyjny analizuje własne odczucia i sytuacje. Ma świadomość kulturowego skryptu kobiecości, ale jednocześnie wyraża wobec niego krytyczny dystans. W czasie balu wybiera partnerów; pierwszego dnia tańczy ze starszym mężczyzną, drugiego z młodym Księciem. Trzeciej nocy, podczas spaceru z Księciem ma epizod bulimiczny, a kiedy ten prosi ją aby go poślubiła, nie potrafi wydobyć z siebie głosu. Ostatecznie wyrzuca niewygodne pantofelki i wsiada do karocy z obcą kobietą/matką chrzestną. Słowa głównej bohaterki: „więc kiedy ona zabiera mnie do domu, albo to ja zabieram ją do domu, a może obie to robimy, najbliżej jak tylko można" mogą stanowić nawiązanie do miłości homoseksualnej ${ }^{10}$.

Bajka o Kopciuszku to, zdaniem Rob Baum, opowieść o kobiecej nienawiści, sabotażu i zazdrości, a przy tym moralna, patriarchalna instrukcja, gdzie

5 S. Saha, T.S. Safri, Cinderella Complex: Theoretical Roots to Psychological Dependency Syndrome in Women, The International Journal of Indian Psychology, 2016, 3, 3, 8, http:/ / oaji.net/ articles/2016/1170-1464772133.pdf, s. 119-120.

${ }^{6}$ D. Haase, The Greenwood Encyclopedia of Folktales and Fairy Tales, London 2008, s. 203.

7 D. Haase, Feminist Fairy-Tale Scholarship, [w:] Fairy Tales and Feminism: New Approaches, red. D. Haase, Detroit 2004, s. 20.

8 Tamże.

9 Tamże.

${ }_{10}$ Podaje za: K. Crowley, J. Pennington, Feminist Frauds on the Fairies? Didacticism and Liberation in Recent Retellings of "Cinderella", Journal of Fairy-Tale Studies, 2010, 24, 2, s. 307-308. 
poczucie sprawstwa podmiotu, jakim jest kobieta - nie istnieje. W zamian za to mamy do czynienia z definiowaniem głównej bohaterki poprzez kategorię braku „dominacji, władzy, męskości”11. Jednocześnie Kopciuszek staje się mityczną bohaterką poprzez swoją symbolikę ukazującą możliwą transformację tożsamości dziewcząt. Definiuje ona

pierwszy wybór romantycznego partnera, ograniczenie i posłuszeństwo, w które socjalizuje się dziewczęta, bezwarunkową miłość rodzinną, (...) ideał urody i zachowania,

\section{także ukazuje potencjał}

nawet najmniej uprzywilejowanej społecznie kobiety do osiągnięcia publicznego sukcesu, zdolność do zwycięstwa we współzawodnictwie z innymi kobietami i udawanie kogoś, kim się nie jest. To są znaczące techniki w walce o męską aprobatę ${ }^{12}$.

Znakomity przykład potencjału emancypacyjnego postaci Kopciuszka można odnaleźć w wierszu Sylvii Plath „Cinderella” (1959). Zdaniem Stephena Goulda Axelroda, poetka zwraca w nim uwagę na wpisaną w kulturę amerykańską sprzeczność między ideałem kobiety jako dekoracyjnego/seksualnego przedmiotu i przejawianym przez nią pożądaniem. Ostatnia fraza wiersza, mająca bez wątpienia kluczowe znaczenie dla poetki, odwołuje się do tykania zegara - symbolizującego upływ czasu. W tym kontekście, nie tylko dosłowny - gdyż za chwilę wybije północ, lecz także ten metaforyczny - przemijanie młodości, strach przed utratą urody ${ }^{13}$. Kopciuszek Sylvii Plath ma szkarłatne pantofelki. Ta współczesna czerwień ma symbolizować nową siłę - siłę kreatywnej wyobraźni i emancypacji od udomowienia ${ }^{14}$. Kopciuszek Plath, inaczej niż w klasycznych wersjach, "tkwi w swoim przebraniu”, a atmosfera lustrzanej sali balowej sprzyja jej „zapożyczonej tożsamości”. Kopciuszek „pragnie zachować swoją podwójną tożsamość”, ponieważ jest świadoma

immamentnej dualności człowieka i wyzwania kreatywnego wykorzystania jej aby walczyć z dezintegracją (...) to, co może wydobyć z wybranej dualności to eksploatacja władzy, którą obdarzają ją czerwone pantofle (...) i pozwalają zachować idealną równowagę między tożsamościami ${ }^{15}$.

${ }^{11}$ R. Baum, After the Ball is Over: Bringing Cinderella Home, Cultural Analysis, 2000, 1, http:/ / socrates.berkeley.edu/ caforum/volume1/vol1_article5.html

12 Tamże.

13 Podaję za: K. Osborne, S.R. Cedars (red.), Sylvia Plath: Poems "Cinderella". Summary and Analysis, http:/ / www.gradesaver.com/sylvia-plath-poems/study-guide/summary-cinderella

14 N.J. Christodoulides, Out of the cradle endlessly rocking: Sylvia Plath as Mother-Creator in Light of Julia Kristeva's Theory of Subject Formation, Stirling 2001, s. 51.

${ }_{15}$ Tamże, s. 53. 
Z kolei, w parodii Kopciuszka napisanej przez Iringa Fetchera i zatytułowanej Cinderella Awakening (Przebudzenie Kopciuszka) nacisk został położony na ideologię seksizmu i kapitalizmu. Kopciuszek jest tu dziewczyną z klasy robotniczej, która zakłada związek pracowniczy i działa na rzecz reformy społecznej ${ }^{16}$.

W końcu w Princesses Forum Lindy Kavanagh Kopciuszek wyśmiewa główny topos klasycznej bajki, pytając:

czy można sobie wyobrazić kogoś, kto wybiera partnera na podstawie rozmiaru buta?

Czy szanująca się kobieta mogłaby funkcjonować z takim mężczyzną?, a Księcia nazywa "macho i idiotą" ${ }^{17}$.

Podobnie jak w przypadku innych najbardziej rozpowszechnionych bajek, Kopciuszek ma szereg wersji. Jednak i tutaj możemy mówić o dwóch głównych - Cendrillon ou la petite pantouffle de vair (Kopciuszek lub Historia małego szklanego pantofelka, Cinderella or The History of the Little Glass Slipper) autorstwa Charlesa Perraulta z roku 1697 oraz Aschenputtel braci Grimm z 1812 roku.

W pierwszej z tych wersji wdowiec poślubia kobietę posiadającą dwie córki z pierwszego małżeństwa. Jego własna córka jest piękną i skromną dziewczyną, która staje się obiektem prześladowań macochy i „przyrodnich” sióstr. Zostaje zdegradowana do służącej, ubranej w łachmany, pilnującej ogniska i wykonującej wszystkie prace w gospodarstwie. Pewnego dnia Książę wydaje dwudniowy bal, podczas którego pragnie znaleźć przyszłą żonę. Kopciuszek też jest zaproszona, jednak nie ma stosownego stroju. Z pomocą przychodzi jej Matka Chrzestna, która wyczarowuje karocę z dyni, konie z myszy, woźnicę ze szczura, a główną bohaterkę przyodziewa w najpiękniejszą suknię i szklane pantofelki. Kopciuszek musi jednak opuścić bal przed północą, gdyż wtedy czar pryśnie. Książę od razu spostrzega piękną dziewczynę i tylko jej poświęca czas na balu. Drugiej nocy Kopciuszek również oczarowany Księciem opuszcza bal nieco po północy, dlatego musi uczynić to w pośpiechu, przez co gubi swój szklany pantofelek. Książę znajduje go i postanawia odnaleźć wybrankę swojego serca. W tym celu wyrusza z pantofelkiem z pałacu, aby wszystkie dziewczęta w Królestwie mogły go przymierzać. Ostatecznie odnajduje Kopciuszka, poślubia go i żyją długo, i szczęśliwie. Oto wersja Charlesa Perraulta.

Autorstwo - najbardziej przemawiającego do masowej wyobraźni - bucika wykonanego ze szkła przypisuje się także Charlesowi Perraultowi. Szkło wydaje się współcześnie dość niedorzecznym materiałem na obuwie, jednak pomysł ten był prawdopodobnie podyktowany niezwykle wysoką wartością, jaką przypisywano mu w siedemnastowiecznej Francji. Jednocześnie szkło

\footnotetext{
${ }^{16}$ Podaję za: V. Joosen, Critical and Creative Perspectives on Fairy Tales, Wayne 2013, s. 60.

${ }^{17}$ L. Kavanagh, Princesses', Forum, 1985, s. 34.
} 
symbolizowało czystość i dziewiczość - jako kruche mogło być zbite tylko raz i nie dało się go ponownie przywrócić do pierwotnego stanu. $Z$ drugiej strony uważa się, że owo szkło jest rezultatem pomyłki translatorskiej; pantoufle de verre stanowi nieudane tłumaczenie pantoufle de vair - pantofli z futra wiewiórki, gdzie słowo vair jako archaiczne określenie futra zostało omylnie przekształcone w znane współczesnym verre (szkło) ${ }^{18}$.

Warto dodać, że w najstarszej wersji Kopciuszka, pochodzącej prawdopodobnie z IX wieku z Chin, najbardziej wymownym symbolem jest bucik pasujący na bardzo małą stopę, która staje się synonimem tego, co "piękne, świadczące o nadzwyczajnym charakterze i dystynkcji" ${ }^{19}$. Świadczy to o zakorzenieniu opowieści w kulturze Wschodu, gdzie małe stopy były seksualnym fetyszem i oznaką arystokratyczności kobiety. Pantofelek Kopciuszka ma jednak własną historię, choć zawsze wykonany jest z ekskluzywnego materiału; u braci Grimm staje się złotym pantofelkiem, natomiast we współczesnej, poetyckiej wersji Sylvii Plath jest szkarłatny ${ }^{20}$.

Wracając do wersji Perraulta, Kopciuszek jest „posłuszny, uległy i pasywny", a jego opowieść została przesiąknięta filozofią samostanowienia, demokracji i nagrody za ciężką pracę ${ }^{21}$. Mamy więc tutaj paradoksalną próbę umieszczenia Kopciuszka w kontekście owej idei self-made-man, przy czym, dodam od siebie, awans społeczny nie następuje tu poprzez mozolne wspinanie się po szczeblach drabiny społecznej, lecz jako nagroda w postaci jednorazowego aktu, jakim jest ponowne spotkanie z Księciem. W tym kontekście warto odwołać się do Kris Jeter, zdaniem której Kopciuszek w wersjach europejskich został przekształcony $\mathrm{z}$

wyraźnie pornograficznej opowieści, która narodziła się we Wschodniej tradycji w interaktywną opowieść mającą na celu wzmocnienie etyki protestanckiej. Przesunięto w niej nacisk z uwielbienia dla przodków, fetyszu stóp, relacji edypalnych z ojcem (...) na dobre życie osiągnięte poprzez trudną i żmudną pracę̨2

Dla mnie jednak ten wariant interpretacji Kopciuszka jest znacznie mniej przekonujący niż ten, który odwołuje się do ideologii loterii i mitu natychmiastowości.

Autorzy drugiej, najbardziej znanej wersji Kopciuszka - bracia Grimm pozbawiają bajkę czaru Matki Chrzestnej i dodają do niej nieco „krwawych

18 P. Delarue, From Perrault to Walt Disney: The Slipper of Cinderella, [w:] Cinderella. A Casebook, red. A. Dundes, Paperback - December 15, 1988, s. 110-111.

${ }_{19}$ B. Bettelheim, The Uses of Enchantment. The Meaning and Importance of Fairy Tales, Journal of American Folklore, 1991, s. 236.

20 S. Plath, Cinderella, The Collected Poems, New York 1981.

${ }^{21}$ K. Jetter, Cinderella: Her Multi-Layered Puissant Messages over Millenia, Marriage and Family Review 1984, 7(3-4), s. 238.

${ }^{22}$ Tamże, s. 239. 
elementów" - złe siostry odcinają sobie palce od stóp, aby dopasować pantofelek, a w ostatniej scenie ślubu Kopciuszka z Księciem, ptaki wydłubują im po jednym oku... Kopciuszek braci Grimm jest przekształconą - na podstawie szeregu innych wersji i źródeł - odmianą arystokratycznej przypowieści Ch. Perraulta, w duchu „realistycznych, brutalnych, nękanych ubóstwem opowieści ucieleśniających późniejsze wartości kultury niemieckiego romantyzmu, nacjonalizmu i rasizmu” które, jak ujmuje to Robert Wexelblatt, „uroczyście ochrzczono mianem Das Deutsche Volk (...) bardziej Teutońskich, a przez to bardziej autentycznych" ${ }^{23}$.

William Hughes Mearns w swoim eseju Footnote to Cinderella (An exposition to teachers only) w znakomity sposób ukazuje proces swoistej germanizacji Kopciuszka przez braci Grimm. Tęsknota ojca Kopciuszka „prawdziwego niemieckiego mężczyzny, który instynktownie mierzy świat poprzez odczucie osobistego komfortu i poczucie wyższości" - jest tęsknotą za zmarłą żoną, która była dobrą gospodynią. Jej miejsce próbuje zająć dobrze wychowana córka, której brakuje jednak „sprawności teutońskiej maszyny". Stąd, postanawia on poślubić wdowę, matkę dwóch córek, która także, jak uważa W.H. Mearns, jest „niemieckim wynalazkiem” ogniskującym w sobie zło i niesprawiedliwość ${ }^{24}$. Heinz Rolleke zwraca także uwagę na niemieckie - teutońskie cechy Kopciuszka braci Grimm: pobożność i prostolinijność ${ }^{25}$.

Warto dodać, że motyw Kopciuszka wyszedł daleko poza przestrzenie stricte kulturowe. Metaforyczne określenie go jest wykorzystywane w naukach inżynieryjnych - w próbkach reprezentatywnych związanych ze współczesnymi instrumentalnymi technikami dystrybucji wielkości cząsteczki. Techniki przesiewania/skanowania w celu analizowania wielkości cząsteczki są określane mianem Kopciuszka - to najbardziej brudna i żmudna praca, która nie ma w sobie nic atrakcyjnego i nie jest doceniana ${ }^{26}$.

Do metafory Kopciuszka wielokrotnie odwołują się także nauki medyczne, na określenie zaniedbanych trendów oraz obszarów w podejmowanych $\mathrm{w}$ nich studiach, badaniach i praktyce. Studia nad tym fenomenem określa się mianem Kopciuszkologii (cinderology) ${ }^{27}$. Lara Hazelton i Cathy Hickey ujmują to następująco:

${ }^{23}$ R. Wexelblatt, Fein on Cinderella, adres internetowy: http://www.abadpennyreview. com/fein-on-cinderella/

${ }^{24}$ W. Hughes Mearns, Footnote to Cinderella (An exposition to teachers only), The English Journal, 1914, 3, 4, s. 220.

${ }^{25}$ D. Haase, Feminist Fairy-Tale Scholarship, s. 20.

26 A.F. Rawle, Representative sampling - another Cinderella of particle size analysis, Procedia Engineering, 2015, 102, s. 1708.

27 L. Hazelton, K. Hickey, Cinderology: The Cinderella of academic medicine, CMAJ, 2004, 171(12). 
rozpoznanie partykularnej choroby czy mechanizmu jako Kopciuszka, może odzwierciedlać protekcyjne przywiązanie do tego obszaru studiów: samotni badacze ciężko pracują nad swoim fragmentem, studiując niejasne medyczne zjawiska, którymi nikt poza nimi nie jest zainteresowany, wyobrażając sobie dzień kiedy 15-hydroxyprostaglandin dehydrogenase znajdzie się w odpowiednim miejscu jak piękność na balu medycyny ${ }^{28}$.

Ponadto, sami badacze mogą uważać się za Kopciuszków, „ignorowanych i pomijanych”, marzących o spotkaniu swojego Księcia, który zainteresuje się ich badaniami na ważnym sympozjum ${ }^{29}$. W każdym razie, jak uważają autorki, użycie słowa Kopciuszek w tytułach artykułów medycznych może być uznane jako „mechanizm radzenia sobie zmierzający do zaciemnienia nieznośnie nudnej natury życiowej pracy autora" ${ }^{30}$.

Z kolei, w naukach politycznych efekt Kopciuszka jest związany z tendencją osób odchodzących $\mathrm{z}$ administracji/polityki do generowania gwałtownych działań regulacyjnych w ostatniej chwili. Jest on definiowany jako wynik połączenia władzy, która wciąż jeszcze jest u władzy, z brakiem odpowiedzialności za podjęte w ostatniej chwili przed odejściem decyzje o charakterze politycznym/ekonomicznym ${ }^{31}$.

Ponadto, Kopciuszka możemy odnaleźć w języku ekonomicznym, gdzie określenie "Cinderella industry” stosuje się wobec przedsiębiorstw, które są niedoceniane i bardzo obciążone dużą liczbą zadań, które trzeba wykonać w krótkim czasie ${ }^{32}$ lub przedsiębiorstwa małej skali, słabo rozwinięte technologicznie ${ }^{33}$.

Skąd bierze się tak silne zakorzenienie symbolu Kopciuszka w społeczeństwach Zachodu? Jak to możliwe, że ta pojedyncza, skromna i niewykształcona dziewczyna może służyć jednocześnie jako symbol bierności i uległości oraz oporu i przekroczenia granic? Jak mogło się stać, że weszła ona w przestrzenie badań naukowych, jakże odległe od pierwotnej idei bajki? W zakończeniu mogę zadać w związku z tym pytanie: czy współcześnie postać Kopciuszka może jeszcze odwoływać się do wyobraźni kobiet i mężczyzn, czy jest już postacią archaiczną? Chyba jednak teza o „,końcu Kopciuszka: nawet w dobie znaczącej emancypacji kobiet” nie byłaby do końca prawdziwa...

\footnotetext{
${ }^{28}$ Tamże.

${ }^{29}$ Tamże.

${ }^{30}$ Tamże.

${ }^{31}$ V. Rugy, A. Davies, Midnight regulations and the Cinderella effect, The Journal of Socio-Economics, 2009, 38, 6, s. 886 .

32 N. Clark, The Cinderella of the Industry, https://www.taus.net/component/easyblog/ the-cinderella-of-the industry?Itemid $=1031 \& \_$hstc $=95936515 . c d e 2 c b 5 f 07430159 d 50 a 3 c 91 e 72 c 2$ 80a.1499299200118.1499299200119.1499299200120.1\&_hssc $=95936515.1 .1499299200121 \&$ hsfp $=1773666937$

${ }_{33}$ Ch. Clark, The British Malting Industry Since 1830, London 1998, s. 33.
} 


\section{BIBLIOGRAFIA}

Baum R., After the Ball is Over: Bringing Cinderella Home, Cultural Analysis, 2000, 1, http:/ / socrates.berkeley.edu/ caforum/volume1/vol1_article5.html

Bettelheim B., The Uses of Enchantment. The Meaning and Importance of Fairy Tales, Journal of American Folklore, 1991.

Christodoulides N.J., Out of the cradle endlessly rocking: Sylvia Plath as Mother-Creator in Light of Julia Kristeva's Theory of Subject Formation, Stirling 2001.

Clark Ch., The British Malting Industry Since 1830, London 1998.

Clark N., The Cinderella of the Industry, https:/ / www.taus.net/component/easyblog/thecinderella-of-theindustry? Itemid $=1031 \&$ _hstc $=95936515$.cde2cb5f07430159d50a3c 91e72c280a.1499299200118.1499299200119.1499299200120.1\&__hssc $=95936515$. $1.1499299200121 \& \_$_hsfp $=1773666937$

Crowley K., Pennington J., Feminist Frauds on the Fairies? Didacticism and Liberation in Recent Retellings of "Cinderella", Journal of Fairy-Tale Studies, 2010, 24, 2.

Delarue P., From Perrault to Walt Disney: The Slipper of Cinderella, [w:] Cinderella. A Casebook, red. A. Dundes, Paperback - December 15, 1988.

Dowling C., The Cinderella Complex: Women's Hidden Fear of Independence, New York 1981.

Haase D., Feminist Fairy-Tale Scholarship, [w:] Fairy Tales and Feminism: New Approaches, red. D. Haase, Detroit 2004.

Haase D., The Greenwood Encyclopedia of Folktales and Fairy Tales, London 2008.

Hazelton L., Hickey K., Cinderology: The Cinderella of academic medicine, CMAJ, 2004, 171(12).

Hughes Mearns W., Footnote to Cinderella (An exposition to teachers only), The English Journal, 1914, 3, 4 .

Jetter K., Cinderella: Her Multi-Layered Puissant Messages over Millenia, Marriage and Family Review 1984, 7(3-4).

Joosen V., Critical and Creative Perspectives on Fairy Tales, Wayne 2013.

Kavanagh L., Princesses', Forum, 1985.

Melosik Z., Uniwersytet i społeczeństwo. Dyskursy wolności, wiedzy i władzy, Poznań 2009.

Melosik Z., Kultura popularna i tożsamość młodzieży. Wniewoli władzy i wolności, Poznań 2014.

Osborne K., Cedars S.R. (red.), Sylvia Plath: Poems "Cinderella” Summary and Analysis, http:/ / www.gradesaver.com/sylvia-plath-poems/study-guide/summary-cinderella

Plath S., Cinderella, The Collected Poems, New York 1981.

Rawle A.F., Representative sampling - another Cinderella of particle size analysis, Procedia Engineering, 2015, 102.

Rugy V., Davies A., Midnight regulations and the Cinderella effect, The Journal of Socio-Economics, 2009, 38, 6 .

Saha S., Safri T.S., Cinderella Complex: Theoretical Roots to Psychological Dependency Syndrome in Women, The International Journal of Indian Psychology, 2016, 3, 3, 8, http:/ /oaji. net/articles/2016/1170-1464772133.pdf

Wexelblatt R., Fein on Cinderella, adres internetowy: http:/ / www.abadpennyreview.com/ fein-on-cinderella/ 